\title{
Trans Men Giving Birth and Reflections on Fatherhood: What to Expect?
}

\author{
Alice Margaria* \\ ${ }^{*}$ Research Fellow, Department of Law and Anthropology, Max Planck Institute for Social Anthropology, Halle (Saale), \\ Germany \\ E-mail: margaria@eth.mpg.de.
}

\begin{abstract}
What was long feared by legislators and courts has now become reality: trans men give birth to their own children and request to be designated as their 'fathers' for the purpose of birth registration. This article sheds light on the transformative potential of such procreative scenarios and the following legal claims for fatherhood. An argument is made that they invite essential reflections on what it means to be a father today and, in so doing, they prompt a (re)construction of legal fatherhood which includes care as a relevant, paternal parameter. By focusing on ongoing cases decided by English and German courts, however, this article shows that domestic courts' understanding of fatherhood has essentially preserved its conventionally heteronormative, biological, and mediated nature. Yet, the game is still open and an application pending before the European Court of Human Rights may breathe fresh air into the debate.
\end{abstract}

\section{I. (TRANS) MEN GIVING BIRTH:}

\section{(LEGAL) PANIC?}

The impact of trans ${ }^{1}$ identities on the establishment of legal parenthood is an emerging subject of interest in socio-legal scholarship. This is not surprising given the concomitantly growing case law on the matter suggesting that it is certainly not too early to investigate the legal reactions to trans parenthood, ${ }^{2}$ especially where the legal determination of parent-child relationships is at stake. Disputes concerning the status of trans parents on their children's birth certificates have indeed started to proliferate as a consequence of a combination of socio-legal and medical developments. ${ }^{3}$ Until

1 I use the term 'trans' to refer to those people whose gender identity differs from the gender assigned at birth.

2 This term should be read as a condensed form of 'trans experiences of parenthood'. The same applies to 'trans fatherhood'.

3 In addition to the cases mentioned in this article, see inter alia $R(J K) v$ Secretary of State for the Home Department [2015] EWHC 990; Gothenburg Administrative Court of Appeals, Skatterverket $v$ A and B, Case No. 6186-14 (5 October 2015); German Federal Court of Justice, XII ZB 459/16, 29 November 2017; French Court of Cassation (first Civil Chamber), Decision No. 519, 16 September 2020 (18$50.080 ; 19-11.251)$.

(C) The Author(s) 2020. Published by Oxford University Press.

This is an Open Access article distributed under the terms of the Creative Commons Attribution License (http://creativecommons.org/licenses/by/4.0/), which permits unrestricted reuse, distribution, and reproduction in any medium, provided the original work is properly cited. 
not long ago, becoming infertile was considered the price to pay for transitioning. ${ }^{4}$ Today, however, one's 'transition's to and legal recognition in the 'preferred gender' is less and less understood as necessarily removing the ability to procreate. As a result, more and more trans people become parents through sexual intercourse, sperm donation, or assisted reproduction ('ART') after legal transitioning. ${ }^{6}$

In the context of trans procreative rights, trans masculine practices of pregnancy and birth have attracted wide media coverage ${ }^{7}$ and sparked 'moral panic'. ${ }^{8}$ This is, inter alia, due to their visible departure from the conventional imaginary of reproduction that portrays 'male' and 'female' contributions as clearly defined and distinct from one another and, in particular, to the challenges they pose to gendered notions of pregnancy. ${ }^{9}$ Indeed, these experiences feature a 'birth-assigned female' trans man who is perceived as appropriating a capacity that is not his. ${ }^{10}$ Apart from pushing us to reconsider the 'fixed naturalness of maleness and femaleness', ${ }^{11}$ pregnant trans men display an unconventional way of entering fatherhood and, as such, stimulate renewed reflection on what it means to be a father in today's world. A context where this reflection occurs is the law and, more specifically, the laws regulating the determination of legal parenthood. Indeed, the situation where a man gives birth has

4 P. de Sutter, 'Transparentalité génétique ou biologique: rêve ou réalité?’ in L. Hérault (ed.), La parenté transgenre (Aix-en-Provence: Presses Universitaires de Provence, 2014) p. 107; G. T'Sjoen, E. Van Caenegem, and K. Wierckx, 'Transgenderism and Reproduction' (2013) 20 Current Opinion in Endocrinology, Diabetes and Obesity 575.

5 'Transition' is herein understood as 'a process whereby an individual "transitions" to living in their preferred gender'. See P. Dunne, 'Transgender Sterilisation Requirements in Europe' (2017) 25(4) Medical Law Review 558. Transition can take various forms and includes some or all of the following personal, medical and legal steps: telling one's family, friends and co-workers; using a different name and new pronouns; dressing differently; changing one's name and/or sex on legal documents; hormone therapy; and, possibly (though not always) one or more types of surgery'. See TGEU, 'Transition', Glossary, https:// tgeu.org/glossary/ (last access on 2 June 2020).

6 On the reproductive options for trans individuals, see C. De Roo et al., 'Fertility Options in Transgender People' (2016) 28 (1) International Review of Psychiatry 112-19; C. Richards and L. Seal, 'Trans People's Reproductive Options and Outcomes' (2014) 40 Journal of Family Planning and Reproductive Health Care 245-47.

7 Inter alia, G. Trebay, 'He's Pregnant. You're Speechless' New York Times, 22 June 2008, https://www. nytimes.com/2008/06/22/fashion/22pregnant.html (last access on 2 June 2020); F. Govan, 'Man Who Become the First in World to Become Pregnant with Twins Seeks New Round of IVF Treatment' The Telegraph, 28 September 2009, https://www.telegraph.co.uk/news/worldnews/europe/spain/6239544/ Man-who-become-first-in-world-to-become-pregnant-with-twins-seeks-new-round-of-IVF-treatment.html (last access on 2 June 2020); N. Brener, 'Israeli Man Gives Birth’ Ynet News, 30 December 2011, https:// www.ynetnews.com/articles/0,7340,L-4169089,00.html (last access on 2 June 2020); T. Payne, 'Britain's First Pregnant Man Gives Birth to a Baby Girl after Conceiving Using a Sperm Donor He Met on Facebook' Daily Mail, 8 July 2017, https://www.dailymail.co.uk/news/article-4676182/Britain-s-pregnantman-gives-birth-baby-girl.html (last access on 2 June 2020); H. Whitehouse, 'Transgender Man Gives Birth to Non-binary Partner's Baby with Female Sperm Donor’ Mirror, 28 December 2019, https://www. mirror.co.uk/news/uk-news/transgender-man-gives-birth-non-21177808 (last access on 2 June 2020).

8 M. Gross, 'Gay, Lesbian, and Trans Families Through the Lens of Social Science: A Revolution or a Pluralisation of Forms of Parenthood?' (2015) 23 Enfances Familles Générations, s 85.

9 S.D. More, 'The Pregnant Man - An Oxymoron?' (1998) 7 (3) Journal of Gender Studies 320.

10 L. Hérault, 'Procréer à la manière des femmes, engendrer en tant qu'homme' in Hérault (n 4) 81.

11 M. Ryan, 'Beyond Thomas Beatie: Trans Men and the New Parenthood' in R. Epstein (ed.), Who's My Daddy? And Other Writings on Queer Parenting (Toronto: Sumach Press, 2009) p. 139. 
sometimes been a source of confusion when establishing legal parenthood. ${ }^{12}$ What parental status should this person be assigned? Should this person be considered the child's 'mother', 'father', or simply 'parent' for the purposes of birth registration?

These questions lie at the root of two ongoing cases concerning trans men who, after being legally recognised as belonging to the male gender, made use of their reproductive organs and gave birth to their children. The first is that of Freddy McConnell, whose son YY was born in January 2018 following intra-uterine insemination using donor sperm. The second regards the - generally lesser known-story of $\mathrm{OH}$, a German trans man who gave birth to his child $\mathrm{GH}$, conceived using donor sperm, in March 2013. ${ }^{13}$ Despite being legally men, McConnell and $\mathrm{OH}$ have been assigned the legal status of 'mother' for the purposes of birth registration. They initiated legal proceedings before English and German courts, respectively, and requested to be legally recognised as 'fathers' of their children - or alternatively as 'parent' or 'gestational parent' in the case of McConnell. In line with the decisions of the Court of Appeal (England and Wales) ${ }^{14}$ and the German Federal Court of Justice ('BGH'), ${ }^{15} \mathrm{YY}$ and $\mathrm{GH}$ continue to have a father in life, but a mother under the law. Yet, hopes remain for their claims to be reconsidered: whilst McConnell has already expressed its wish to bring his case before the European Court of Human Rights ('Court' and 'ECtHR'), ${ }^{16}$ the case of $\mathrm{OH}$ and $\mathrm{GH}$ has already crossed national borders and is currently pending before Section V of the ECtHR. ${ }^{17}$

Taking its cue from these cases, this article contributes to wider debates on changing realities of 'fatherhood' and how the law 'makes sense' of them. More specifically, its aim is two-fold. First, it seeks to display the transformative potential of these cases. In giving birth to their children and seeking to be recognised as their 'fathers', trans men are 'active agents' ${ }^{, 18}$ in challenging a 'conventional' understanding of fatherhood and, more importantly, in making care a relevant characteristic of legal fatherhood. Secondly, this article engages with the law's response to this challenge, in particular, that of domestic courts which have recently intervened on the matter and - in prospective terms - that of the ECtHR.

The analysis is structured around five sections. Section 2 delves into the cases of $\mathrm{McC}$ Connell and $\mathrm{OH}$ and outlines the key arguments advanced by domestic courts to confirm the designation of the applicants as 'mothers'. Section 3 introduces the paradigm of 'conventional fatherhood' and shows that the transformative potential of these cases has gone largely unused - so far. In the subsequent two sections, the focus shifts to the ECtHR. Section 4 takes stock of the relevant case law on family

12 In this sentence, 'man' refers to a person whose gender identity and legal gender are that of a man.

13 In national proceedings, they carry different appellations: OG (trans man) and GP (his child).

$14 R$ (McConnell and YY) v Registrar General [2020] EWCA Civ 559, 29 April 2020. On 9 November 2020, the Supreme Court refused McConnell's application for permission to appeal because it did 'not raise an arguable point of law'.

15 BGH XXI ZB 660/14, 6 September 2017.

16 R. Booth, 'Trans man loses UK legal battle to register as his child's father' The Guardian, 16 November 2020, https://www.theguardian.com/society/2020/nov/16/trans-man-loses-uk-legal-battle-to-register-ashis-childs-father (last access on 6 December 2020).

17 O.H. and G.H. v Germany, Application Nos. 53568/18 and 54941/18, communicated on 6 February 2019. 
rights, and it traces the Court's tendency to accept as meritorious only those fathers and, more generally, families who - albeit 'unconventional' - succeed in mimicking the 'conventional'. Taking a forward-looking attitude, Section 5 identifies some relevant doctrinal elements which might contribute to shape the Court's reasoning in the pending case of O.H. and G.H. $v$ Germany. In the light of the discretion enjoyed by Strasbourg judges, an argument is made that the extent to which the forthcoming judgment will rethink fatherhood beyond the conventional paradigm is likely to be not just the 'product of doctrines, ${ }^{19}$ but also a 'matter of choice'. The final section (6) shares some reflections on de-gendering legal parenthood as a possible future course in the context of trans parenthood and beyond.

\section{RECENT DEVELOPMENTS BEFORE DOMESTIC COURTS: MC CONNELL, OH, AND THEIR CHILDREN}

\section{Trans Masculine Pregnancy and Birth in Practice}

Most trans people are of reproductive age at the moment of transition ${ }^{20}$ and engage in post-transition relationships. ${ }^{21}$ The desire for parenthood is present in many of them, as in the rest of the population. ${ }^{22}$ A Belgian study more specifically exploring the reproductive wishes of trans men following gender confirmation surgery showed that, at the time of interview, more than half desired to have children. ${ }^{23}$ In another study, concerning the trans population in France, the same wish was identified amongst a group of trans men who had not undergone any genital surgery. ${ }^{24}$ In practice, trans men can become biological parents in multiple ways depending on their specific circumstances. For instance, if a female partner is present, she can be inseminated with sperm from a donor. Whilst it remains true that gender confirmation surgery leads to an irreversible loss of reproductive potential, a recent study has shown that hormone therapy does not impact egg yields for trans men. ${ }^{25}$ Moreover, current and future reproductive technologies - such as freezing of oocytes, embryos, or ovarian tissue - give trans men the opportunity to have children using their own gametes in the future. ${ }^{26}$

P. Johnson, Homosexuality and the European Court of Human Rights (London: Routledge, 2013) p. 88.

20 This is also due to restrictive policies around children. See P. Dunne, 'Transgender Children and the Law' (2017) Family Law 123-24. For recent data on age requirements for legal gender recognition, TGEU, 'Trans Rights Europe \& Central Asia Index 2019' https://tgeu.org/trans-rights-europe-centralasia-map-index-2019/ (last access on 2 June 2020).

21 T'Sjoen, Van Caenegem, and Wierckx (n 4).

22 Ibid.

23 K. Wierckx et al., 'Reproductive Wish in Transsexual Men' (2012) 27 Human Reproduction 483-87.

24 A. Giami, 'Procréation et parentalité dans la population trans - Genre parcours, biographique, parcours de transition' in Hérault (n 4) 101 and 102.

25 E. Powys Maurice, 'Trans Men Who've Been on Testosterone Can Be Just as Fertile as Cis Women, Landmark Study Finds’ Pink News, 16 April 2020, https://www.pinknews.co.uk/2020/04/16/trans-mentestosterone-fertility-boston-ivf-study-hormone-therapy-cis-women-egg-yield/ (last access on 2 June 2020). Moreover, both cases discussed in the next subsection prove that previous testosterone use did not impede McConnell and OH's pregnancies.

26 T'Sjoen, Van Caenegem, and Wierckx (n 4) 577 and 578; P. De Sutter, 'Gender Reassignment and Assisted Reproduction: Present and Future Reproductive Options for Transsexual People' (2001) 16 (4) Human Reproduction 613-14. 
Another possibility is transmasculine pregnancy and birth. ${ }^{27}$ Its viability has increased following, inter alia, a shift in national frameworks regulating gender recognition. Until recently, persons who desired to transition to and be legally recognised in another gender had to undergo gender confirmation surgery, sterilisation, or a combination of the two in most jurisdictions. As a result, trans families and individuals were - and in certain jurisdictions are still - forced to choose between recognition of their gender identity and their right to reproduce. One of the driving concerns was and is exactly to prevent procreative practices considered undesirable and problematic, with a particular fear of 'pregnant men'. ${ }^{28}$

In recent years, however, the trans community and an increasing number of political and legal actors have started to question the legitimacy of surgery and sterilisation practices and their indispensability as prerequisites to recognise a person's gender identity. ${ }^{29}$ Judges have also become generally more suspicious of (especially some) ${ }^{30}$ medical interventions in the process of gender recognition. In 2017, the ECtHR established that surgical or medical procedures involving a high probability of sterility are not acceptable requirements for obtaining gender recognition under the Convention. ${ }^{31}$ Even before, similar outcomes had been reached by national courts in Germany, ${ }^{32}$ Sweden, ${ }^{33}$ and Italy, ${ }^{34}$ thus moving towards a progressive weakening of the requirements that trans individuals should modify their body in order to be legally recognised in their preferred gender.

Against this background, trans men who do not undertake surgery to remove their reproductive organs, retain the capacity to achieve pregnancy and, if they desire to do so, can give birth to their own children. ${ }^{35}$ This is the procreative path which

27 It is important to note that young trans men (and trans masculine non-binary persons), who do not experience female puberty, will never have the possibility of becoming pregnant men.

28 P. Currah, 'Expecting Bodies: The Pregnant Man and the Transgender Exclusion from the Employment Non-discrimination Act' 200836 (3\&4) Women's Studies Quarterly 330; J.M. Scherpe and P. Dunne, 'The Legal Status of Transsexual and Transgender Persons - Comparative Analysis and Recommendations' in J.M. Scherpe (ed.), The Legal Status of Transsexual and Transgender Persons (Cambridge: Intersentia, $2015)$ p. 648.

29 In this sense, the UK Gender Recognition Act 2004 set an example with a considerable impact on gender recognition laws across Europe. See also inter alia The Yogyakarta Principles (2006), Principle No. 3; PACE, Resolution 2048 (2015) Discrimination Against Transgender People in Europe, s 6.2.2, 22 April 2015. For an overview of legal gender recognition requirements in the EU, see Legal gender recognition in the EU: the journeys of trans people towards full equality (Luxembourg: Publications Office of the European Union, 2020), ch 6.

30 Courts are more suspicious about medical interventions which lead to sterilisation (examples in nn 32-34 below), but less about surgery and certainly less sceptical about diagnosis. This is also confirmed in the ECtHR's jurisprudence. See A.P., Garçon and Nicot v France Applications, Nos. 79885/12 52471/13 and 52596/13, 6 April 2017; Y.Y. v Turkey, Application No. 14793/08, 10 March 2015; P. Dunne, 'Legal Gender Recognition in Europe: Sterilisation, Diagnosis and Medical Examination Requirements' (2017) 39 (4) Journal of Social Welfare and Family Law 497-500.

31 A.P., Garçon and Nicot v France, Ibid. See also Y.Y. v Turkey, Ibid.

321 BvR 3295/07 German Constitutional Court (11 January 2011).

33 Stockholm Administrative Court of Appeals, Socialstyrelsen v NN, Mål nr 1968-12 (19 December 2012).

34 Constitutional Court of Italy, 221/2015 (21 October 2015).

35 That is not to say that it is an easy endeavour. See, inter alia, J.M. Grant et al., National Transgender Discrimination Survey Report on Health and Healthcare (Washington: National Center for Transgender Equality and National Gay and Lesbian Task Force, 2010) pp. 1 and 23; S. Marcus Ware, 'Boldly Going Where Few Men Have Gone Before: One Trans Man's Experience' in Epstein (n 11) pp. 65-72; Seahorse, Documentary (by J. Finlay), https://seahorsefilm.com (last access on 2 June 2020) . 
McConnell and $\mathrm{OH}$, amongst others, ${ }^{36}$ have taken in order to become parents after transitioning. Let us take a closer look at their specific stories. ${ }^{37}$ After being legally recognised as male (April 2017), McConnell successfully underwent intrauterine insemination fertility treatment and gave birth to his son YY, in January 2018. Similarly, $\mathrm{OH}$ was recognised as belonging to the male gender by a court order in 2011, after having his female first name (BD) changed into his current male name (OH). In March 2013, he gave birth to his child, GH, who was conceived through at-home insemination using the sperm of a donor, who had agreed not to claim any rights over the child.

\section{2. ... But in the Law?}

Despite being able to realise their parental projects, McConnell and $\mathrm{OH}$ (and their children) continue to face significant obstacles on their road to legal parenthood. On the basis of the decision of the BGH (confirming the rulings of lower courts), ${ }^{38}$ the Registry Office registered $\mathrm{OH}$ under his former female name as GH's 'mother' in the birth register. ${ }^{39}$ Similarly, McConnell was registered as the 'mother' on the birth certificate of his son. The Registrar's refusal to recognise him as YY's 'father' was upheld by the High Court of Justice ('High Court') 40 and, subsequently, by the Court of Appeal.

The applicant fathers wished to be attributed the status of 'father' or otherwise, in the case of McConnell, that of 'parent' or 'gestational parent'. To that purpose, they contested their designation as 'mothers' by submitting a two-pronged claim. First, they argued that, as a matter of domestic law, they should have been regarded as being male also for the purpose of determining their status as parents and, therefore, should have been registered as 'fathers' of their children (born after transition). ${ }^{41}$ In their view, national provisions are unequivocal in stipulating that only parent-child relationships created before transition are unaltered by the (subsequent) legal recognition of the (then) parent's gender identity. ${ }^{42}$ Secondly, even assuming that the

36 In spite of the lack of exact figures, existing data suggest that trans masculine experiences of pregnancy and birth are more frequent than may be expected. To illustrate, 205 men are recorded to have given birth in the period 2013-2018 in Australia alone. Australian Government, Department of Human Services, Medicare Item 16519 Processed from July 2013 to June 2018, http://medicarestatistics.humanservi ces.gov.au/statistics/do.jsp?_PROGRAM=/statistics/mbs_item_age_gender_report\&VAR=services\& STAT $=$ count $\&$ PTYPE $=$ finyear $\& S T A R T \_D T=201307 \& E N D \_D T=201806 \& R P T \_F M T=$ by + time + period + and + state $\&$ GROUP $=16519$ (last access on 2 January 2020). In addition to frequent media reports (n 7), further evidence is provided by A. Light et al., 'Transgender Men Who Experienced Pregnancy after Female-to-Male Transitioning' (2014) 124 (6) Obstetrics and Gynecology 1120-27.

37 The following account is limited to the factual circumstances which are strictly relevant to the present analysis. More detailed factual background can be found in $R$ (McConnell and YY) (n 14) paras 5-12; BGH (n 15) paras 2-6.

38 AG Berlin, Entscheidung vom 13 December 2013 - 71 III 254/13; Kammergericht Berlin, Entscheidung vom 30 October 2014 - $1 \mathrm{~W} 48 / 14$.

39 An attempt was made to have the case considered by the German Constitutional Court, but it failed.

40 Re TT and YY [2019] EWHC 2384, 25 September 2019.

$41 \quad R$ (McConnell and $Y Y)$ (n 14) para 10; BGH (n 15) para 5.

42 In the UK, legal gender recognition is regulated by the Gender Recognition Act 2004. In McConnell's case, the key provisions are Sections 9 and 12. Section 9 (General) provides that: (i) 'Where a full gender recognition certificate is issued to a person, the person's gender becomes for all purposes the acquired gender (so that, if the acquired gender is the male gender, the person's sex becomes that of a man and, if 
court interprets national provisions in conformity with the Registrar's decision, the applicants argued that the registration systems breached their right to respect for private and family life under Article $8 \mathrm{ECHR}$, in conjunction with Article $14 \mathrm{ECHR}$. Domestic courts responded unfavourably to both arguments. ${ }^{43}$

Agreeing with the applicants, both the BGH and English courts acknowledged some of the difficulties arising from incongruence between their lived and legal realities. In McConnell's case, domestic courts observed that he would be required to produce a full birth certificate - as opposed to a short one which omits his status as 'mother' - only on a limited number of occasions, thus implying that disclosure would be a rare occurrence. ${ }^{44}$ Nevertheless, the situation where the state requires a trans person to declare in an official document that their gender is not their legal gender but the gender assigned at birth constitutes - according to the Court of Appeal - a 'significant' interference with the person's sense of identity. ${ }^{45}$ It also represents - so the Court of Appeal continues - an interference with the right to respect for family life of both McConnell and YY because, in so doing, the state describes their relationship as being mother-son on the long form of the child's birth certificate, whilst their relationship is in fact father-son. ${ }^{46}$ Similarly, the BGH emphasised the importance to have one's name and gender change reflected in public records in order to protect the person concerned against unwanted disclosure of one's trans history and, therefore, against the risk of ill-treatment and discrimination by third parties. $^{47}$

it is the female gender, the person's sex becomes that of a woman)'; (ii) 'Subsection (1) does not affect things done, or events occurring, before the certificate is issued; but it does operate for the interpretation of enactments passed, and instruments and other documents made, before the certificate is issued (as well as those passed or made afterwards)'; (iii) 'Subsection (1) is subject to provision made by this Act or any other enactment or any subordinate legislation'. Section 12 GRA (Parenthood) provides that: 'The fact that a person's gender has become the acquired gender under this Act does not affect the status of the person as the father or mother of a child.' In Germany, the regulation of trans identities is included in the Transsexual Act 1980 and the relevant provisions are s 10(1) (effects of the decision): 'Once the decision that the applicant is to be considered to belong to the opposite gender has become final, his or her gender related rights and duties shall be governed by the new gender unless otherwise stated by law'; s 11(1) (parent-child relationships): 'The decision that the applicant is to be considered as being of the opposite sex leaves the legal relationship between the applicant and his parents or between the applicant and his children unaffected, but in the case of adopted children only to the extent that they were adopted as children before the decision became final. The same shall apply in relation to the descendants of such children.' (author's translation)

43 National rulings are herein analysed jointly because they share their core reasoning. Yet, it should be borne in mind that McConnell's and OH's cases arise in legal contexts whose approaches to trans identities have significant differences, especially from a historical perspective. For instance, whilst the UK Gender Recognition Act 2004 never included a surgery or sterilisation requirement, in the German context, the possibility of a trans person conceiving their own biological child was originally barred by the sterilisation requirement included in the Transsexual Act 1980 (a requirement which was declared unconstitutional only in 2011). For an overview of the German legal approach to this field, see A. Dutta, 'The Legal Status of Transsexual and Transgender Persons in Germany' in Scherpe (n 28) 207-21; F. Furkel, 'The Impact of Biomedicine on Parenthood in Germany or the Obsession of the Biological Truth' in B. Feuillet-Liger, T. Callus, and K. Orfali (eds), Reproductive Technology and Changing Perceptions of Parenthood Around the World (Bruxelles: Bruylant, 2014) pp. 33-62.

44 Re TT and YY (n 40) para 272; R (McConnell and $Y Y$ ) (n 14) para 55.

$45 \quad R$ (McConnell and $Y Y)$ (n 14) para 55.

46 Ibid.

47 BGH (n 15) para 35. 
Yet, in the balancing exercise undertaken by the courts, these concerns eventually succumbed to a need for 'certainty in family law' which is - not by chance - one of the primary rationales which has been commonly advanced against procreation post-transition by courts and legislators. ${ }^{48}$ As explained by Dunne, the argument in favour of sterilisation requirements for gender recognition has often been that allowing men to give birth would (i) 'destabilise Europe's family law systems', and (ii) confuse children about their biological origins and deprive them of important family relationships. ${ }^{49}$ Even if neither the UK Gender Recognition Act 2004 ('GRA') nor the German Transsexuals Act 1980 ('TSG') (as amended by the Constitutional Court $)^{50}$ includes such requirements, these justifications lie at the heart of the reasoning put forward by English courts and the BGH in the cases under examination.

Domestic courts indeed stressed the need to preserve an administratively coherent and certain scheme for the registration of births in which the person who gives birth is consistently registered as 'mother', in accordance with the rule mater semper certa est. $^{51}$ The BGH explains that, in the German legal system, this rule $\mathrm{e}^{52}$ and, more generally, the determination of legal parenthood on the grounds of the biological contribution of the parent to the child's conception ${ }^{53}$ are considered to pursue a legitimate aim of the Legislator: to legally assign children to their biological parents in such a way that their parentage is not attributed to two legal mothers or fathers, contrary to biological reality. ${ }^{54}$

Also, the provisions of the GRA ${ }^{55}$ and the $\mathrm{TSG}^{56}$ which more specifically regulate the parental status of trans individuals are to be read against this background according to the courts: the fact that a person has changed legal gender does not affect the parental status of that person, both retrospectively - ie with respect to children born before transition - and prospectively - ie with respect to children born after transition. ${ }^{57}$ The BGH explains that this would ensure that children are always assigned a mother and a father, despite the parent's legal gender change. ${ }^{58}$ A similar concern for the interests of children has seemingly guided the UK Legislator's efforts in 'enacting a carefully crafted' registration scheme as well. ${ }^{59}$ As explained by English courts, Parliament has indeed taken into account the best interests of children as a primary consideration when striking a balance between the rights of trans parents and others, including their children, ${ }^{60}$ and eventually given priority to the 'need for clarity as to parental status'. ${ }^{61}$

49 Ibid.

501 BvR 3295/07 (n 32).

51 BGH (n 15) para 27; $R$ (McConnell and $Y Y$ ) (n 14) paras 64-71.

$52 \$ 1591$ BGB. See $\$ 1592$ BGB on the legal establishment of fatherhood.

53 BGH (n 15) para 25.

54 Ibid, para 9.

55 See GRA provisions (n 42).

56 See TSG provisions ( $\mathrm{n} 42$ ).

57 BGH (n 15) para 8; R (McConnell and YY) (n 14) paras 29-33.

58 BGH (n 15) para 19.

$59 R$ (McConnell and YY) (n 14) para 86.

60 Ibid.

61 Re TT and $Y Y$ (n 40) para 263. 
One of the reasons, possibly the most compelling one, underlying the abovementioned legislative choices lies in the importance attached to the right of children to know their origins. According to the $\mathrm{BGH}$, should birth registration not clarify the exact biological reproductive function - ie, giving birth or contributing with sperm to the child's conception - in which the establishment of the parent-child relationship is grounded, the child would be deprived of vital information on its descent. ${ }^{62}$ However, both the BGH and English courts seem to endorse a specific interpretation of the right to know one's origins. By referring to the views taken by Parliament, the Court of Appeal explicitly holds that 'every child should . . . be able to discover who their mother was. ${ }^{63}$ Apart from the right of children to know their mother, the outcome sought by the applicants is understood to contravene more profoundly a 'right to a mother' which every child supposedly has. ${ }^{64}$ The High Court elaborated on this point more vocally than the Court of Appeal ${ }^{65}$ and explained that registering a trans man who gave birth as the child's 'father' or 'parent' implies that this child 'will not have, and will never have had, a "mother" as a matter of law, he will only have a father ${ }^{66}$ According to English courts, this outcome would run counter to the child's best interests to have a mother and to know who that person is. ${ }^{67}$

All in all, the adverse consequences suffered by $\mathrm{McC}$ Connell, $\mathrm{OH}$, and their children were considered to be significantly outweighed by the rights of any child born from a trans man and the public interest in preserving the 'ordering function ${ }^{68}$ of civil status rules. As a result, both the BGH and English courts confirmed that the applicant fathers had to be registered as 'mothers' of their children and excluded any violation of their right to respect for private and family life. Domestic courts further argued that McConnell's and OH's ability to bear children and actual experience of giving birth placed them in a position not comparable to that of other legal men or groups of parents, thus rejecting their complaint of discrimination. ${ }^{69}$

\section{3. (Still) 'Gendering' Parenthood}

These decisions have been received by some as offering a definition of legal motherhood which, possibly inadvertently, breaks away from normative understandings of gender, reproduction, and parenting. ${ }^{70}$ In the words of McFarlane (President, High Court) - later reiterated by the Court of Appeal ${ }^{71}$ - motherhood should be

62 BGH (n 15) para 29.

$63 R$ (McConnell and $Y Y$ ) (n 14) para 86. Similarly, the High Court referred to the 'right to know who gave birth to them' as a core element of the right of children to establish the substance of their identity. Re TT and $Y Y(\mathrm{n} 40)$ para 256.

64 G. Baars, 'Queer Cases Unmake Gendered Law, or, Fucking Law's Gendering Function' (2019) 45 (1) Australian Feminist Law Journal 43.

$65 R$ (McConnell and YY) (n 14) para 86.

66 Re TT and $Y Y$ (n 40) para 258.

67 Ibid; $R$ (McConnell and $Y Y$ ) (n 14) para 86.

68 BGH (n 15) para 9. Original text: 'Ordnungsfunktion des Personenstandsrechts'.

69 Ibid, para 32; R (McConnell and YY) (n 14) paras 85 and 86 referring to Re TT and $Y Y$ (n 40) ss 274-77.

70 R. Pearce et al., 'Of Trans Fathers and Male Mothers - The Importance of Centering Experience' (8 October 2019) https://ruthpearce.net/2019/10/08/of-trans-fathers-and-male-mothers-the-importanceof-centering-experience/ (last access on 2 June 2020). 
understood as a free-standing term which refers to the person who 'undergoes the physical and biological process of carrying a pregnancy and giving birth, ${ }^{72}$ regardless of the legal gender of that person. In so arguing - according to the Court of Appeal - existing provisions and the word 'mother' are given an interpretation which keeps up with contemporary and social norms. ${ }^{73}$ Whilst this is certainly highly debatable, these decisions endorse - more or less explicitly - a 'new' legal construction of 'motherhood' which is based on the reproductive experience, ${ }^{74}$ rather than on the traditionally sex/gendered body, and is as such no longer the exclusive domain of women. As a result, they contest the 'binary' presumption - along which lines legal parenthood is organised - that men are 'fathers' and women are 'mothers'.

Nonetheless, these domestic rulings remain 'disappointing "75 and problematic in many respects. Confirming the designation of $\mathrm{McConnell}$ and $\mathrm{OH}$ as 'mothers' of their children flies in the face of their actual family lives. $\mathrm{OH}$ and McConnell selfidentify as 'fathers'. The children will grow up experiencing them as their fathers. Yet, according to the law (and the law alone), they are 'mothers'. Moreover, to claim that McConnell's registration as 'mother' does not necessarily indicate that he is female - as English courts explicitly did - clashes with the social reality that almost everyone who McConnell shall meet will understand his status as 'mother' in traditionally gendered terms. Hence, whilst the court may claim that McConnell is a 'male mother, ${ }^{76}$ society will understand his maternal status as being indicative of the female legal gender and will treat McConnell as such.

Additionally, at a more structural level, these decisions confirm or even reinforce the 'law's gendering function'.7 They exhibit the role of state institutions and officials in regulating family relationships (and, more widely, people's lives) on the basis of 'an ideological commitment to a strict gender binary and heteronormative family structure'. ${ }^{78}$ In the cases at hand, this commitment becomes particularly clear when taking into account the construction of fatherhood which - more subtly, if compared to motherhood - shines through in these decisions. Refusing to recognise legal men giving birth as 'fathers' can indeed be read as revealing the law's reluctance 'to allow trans men to ascend to key male roles like "father". ${ }^{79}$ In the same vein, an argument could be made that registering them as 'mothers' entails that, in the eyes of the law, they are still sufficiently female to be named as such. ${ }^{80}$ One, and possibly the main, ratio underlying the rule mater semper certa est - as confirmed by the Court of Appeal in the case of McConnell $-^{81}$ is to make sure every child has at least one

$72 \operatorname{Re} T T$ and $Y Y(\mathrm{n} 40)$ para 279.

$73 R$ (McConnell and $Y Y)$ (n 14) para 34.

74 Pearce et al. (n 70).

75 Ibid; L. Russell, 'Statement on the Ruling Against Freddy McConnell' 29 April 2020, https://www.stone wall.org.uk/about-us/news/statement-ruling-against-freddy-mcconnell.

76 Re TT and $Y Y$ (n 40) para 280.

77 Baars (n 64) 30.

78 Ibid 16. See also D. Leibetseder and G. Griffin, 'States of Reproduction: The Co-production of Queer and Trans Parenthood in Three European Countries' (2020) 29 (3) Journal of Gender Studies 313.

79 Baars (n 64) 41.

80 I wish to thank one of the anonymous reviewers for drawing my attention to this further reading of the domestic rulings.

$81 R$ (McConnell and YY) (n 14) para 64. 
caring person in their lives. Although gender-neutral in its formulation, this ratio is in fact potentially grounded in a gendered assumption: at the moment of birth, the person who is ready and able to become responsible for the care of a newly born child is who we call a 'mother'. The resulting image of 'the father' as sketched by the English courts and the BGH is examined in the next section.

\section{III. 'CONVENTIONAL FATHERHOOD' AND THE PREGNANT (TRANS) MAN: POTENTIAL AND REAL CHALLENGES}

Trans experiences of parenthood confront us with a variegated reality where men can achieve pregnancy and give birth to their children, and women can conceive using their sperm. This reality is at odds with the 'dominant ideology of the family ${ }^{82}$ which identifies the heterosexual, marital family with biological children as the 'ideal' locus in which to raise children. It further challenges the construction of parenting as a 'gendered enterprise', 83 which is central to this ideology and ascribes maternal and paternal features and roles to people depending on their sex. ${ }^{84}$ Apart from occupying a significant place in common imagination, this ideology has also penetrated the way in which the law defines and regulates 'fatherhood' and 'motherhood', respectively.

According to what I have previously termed 'conventional fatherhood', being a father has been generally understood as being at the same time the biological progenitor of the child who has contributed sperm to the child's conception, married or in a stable relationship with the child's mother; heterosexual and 'cis ${ }^{85}$; and the family breadwinner. ${ }^{86}$ Conversely, caring roles have been traditionally associated with maternal and female figures. As a result, paternal involvement in the child's life has long been considered irrelevant to make someone a (legal) father. ${ }^{87}$ This goes hand in hand with the 'mediated' nature of fatherhood. The marital presumption is possibly its most blatant manifestation, as fatherhood has been conventionally framed as a derivative of the mother-father relationship, rather than a direct and autonomous tie.

Apart from describing what allegedly used to be the most widespread reality of fatherhood, 'conventional fatherhood' tends to express a normative vision of the 'good' father and, indirectly, of the appropriately constituted family. To the extent that it has permeated the formulation and application of the law, 'conventional fatherhood' has concrete repercussions for the lives of fathers, children, mothers, and other caregivers involved. Indeed, it contributes to identifying which father-child relationships deserve a legal existence, and concurrently, to sanctioning those which do not match the 'ideal' with a lack of recognition.

Pregnant trans men who give birth to their children, like McConnell and $\mathrm{OH}$, depart from 'conventional fatherhood' in many ways. First, whilst it is true that there

C. McGlynn, Families and the European Union: Law, Policy and Pluralism (Cambridge: Cambridge University Press, 2006) p. 23.

83 Ryan (n 11) 141.

84 D. Rosenblum et al., 'Pregnant Man? A Conversation' (2010) 22 Yale Journal of Law and Feminism 269.

85 'Cis' is a term used to describe non-trans people. See TGEU (n 5) 'Cisgender or Cis'.

86 A. Margaria, The Construction of Fatherhood: The Jurisprudence of the European Court of Human Rights (Cambridge: Cambridge University Press, 2019) pp. 13 and 14. 
exists a biological connection between the father and his child, this connection is not of the 'conventional' type. The trans man involved has conceived using his ovaries and uterus (rather than sperm), and therefore, he contributes to reproduction by gestating the pregnancy and, depending on the case, ${ }^{88}$ by providing oocytes as well. Consequently, he lacks the 'typically paternal' biological connection with his child. Secondly, trans masculine practices of pregnancy and birth challenge the tenacity of 'heteronormativity ${ }^{89}$ as a defining characteristic of fatherhood. The law is faced with a scenario where cismasculinity is highly endangered. ${ }^{90}$ In particular, the image of the trans father who gives birth does not only clash with the allegedly stable and fixed nature of gender (which is the core of heteronormativity), but it also breaks away from the assumption that 'one's sex, gender identity and identification as mother/father neatly align'. 91 Thirdly, McConnell and $\mathrm{OH}$ are single fathers as far as known. ${ }^{92}$ As a result, their connection to their children is autonomous and direct rather than mediated by a hypothetical female partner and mother of the child.

Trans men giving birth to their children therefore challenge the conventional paradigm of fatherhood in a rather holistic way. Accordingly, this appears to be an especially fruitful context in which to assess the law's appreciation (if any) of care and caring intentions in making someone a legal father. In regulating the position of other 'unconventional' fathers - such as unmarried or separated fathers, and cis fathers of children born through ART - legal actors have often remedied the absence of a conventional feature by resorting to another conventional attribute as a ground for granting legal fatherhood. ${ }^{93}$ For example, Collier and Sheldon have identified a 'geneticisation' of fatherhood, ${ }^{94}$ namely an enhanced focus on biological ties as a response to the weakened role of marriage in making someone a legal father. This is not at all surprising at a time when heightened separation/divorce rates, the proliferation of non-marital families, and DNA technology concur in depriving the institution of marriage of its status as the sole or primary ground on which to grant paternal status. In the context under analysis, however, similar moves are less of a

88 In the well-known case of Thomas Beatie, for instance, the oocyte donor was Thomas' (former) wife, Nancy, who could not have children.

89 This term (and its relationship with 'cisnormativity') is herein understood to be in line with the definition by Baars (n 64) 18: 'the general assumption of the gender binary of two stable and fixed sexes who are attracted to each other to form monogamous pair bonds aimed at procreation'.

90 Baars (n 64) 40.

91 L. Karaian, 'Pregnant Men: Repronormativity, Critical Trans Theory and Re(conceive)ing of Sex and Pregnancy in Law' (2013) 22 (2) Social and Legal Studies 213.

92 This refers to the summary of facts included in the judgments of the High Court and BGH, together with media reports. McConnell and his partner $\mathrm{CJ}$ initially desired to have a child together. However, $\mathrm{CJ}$ later changed their mind and decided not to parent the child with McConnell changed their mind and, throughout the pregnancy, decided not to parent the child with McConnell. See S. Hattenstone, 'The Dad Who Gave Birth: "Being Pregnant Doesn't Change Me Being a Trans Man”' The Guardian, 20 April 2019, https://www.theguardian.com/society/2019/apr/20/the-dad-who-gave-birth-pregnant-trans-freddymcconnell (last access on 2 June 2020). OH divorced his husband 1 month before giving birth. If his marriage had not been dissolved before the birth, his then husband would have automatically become the child's legal father.

93 Margaria (n 86) 151.

94 R. Collier and S. Sheldon, Fragmenting Fatherhood: A Socio-Legal Study (Oxford: Hart, 2008) pp. 225 and 226. See also, in relation to US law, N. Dowd, 'From Genes, Marriage and Money to Nurture: Redefining Fatherhood' (2003-2004) 10 Cardozo Women's Law Journal 132-45. 
possibility. In the face of trans men giving birth to their children, courts are left with a restricted margin of manoeuvre, which forces them to consider not only the relevance, but more controversially, the sufficiency of the father's involvement in the child's life as a ground for attributing the status of legal father. Exactly because of this, these cases offer precious opportunities to rethink fatherhood beyond the conventional paradigm.

As regards the decisions in the cases of McConnell and $\mathrm{OH}$, however, these opportunities have thus far not been sufficiently grasped. Whilst it is true that, for the purposes of legal gender recognition, biology is de facto challenged by not depriving a legal man of his reproductive ability to give birth, when it comes to legal parenthood, domestic courts continue to attribute parental status on the grounds of birth-assigned gender. As a result, the trans man who gives birth is depicted as 'not a real man', even if his legal gender indicates him to be, and therefore not a man deserving and capable to become a father. ${ }^{95}$

Such an attitude reveals a persisting attachment to a heteronormative and biological understanding of fatherhood. More explicitly, domestic courts seem to suggest that, in order to be legally registered as a father, a person needs to be assigned male gender at birth or otherwise participate in the procreation experience as a 'male'. By giving priority to birth-assigned gender when determining parenthood, the law 'reconstitutes the biological link between semen and man/father', thereby privileging a cisgender reality. ${ }^{96}$ Moreover, fatherhood continues indirectly to be constructed as in need of a (female) connector to be legally relevant. Given their direct tie with the child as a consequence of the absence of a female/maternal figure, according to domestic courts, McConnell and $\mathrm{OH}$ can just be 'mothers'. The emerging understanding of fatherhood, therefore, remains quite solidly anchored to the conventional paradigm.

This outcome is not surprising, especially in the light of the reasoning adduced by English courts and the BGH (examined in the previous section). Despite the European trend described in Section 2, the fact that legal gender recognition increasingly takes place without a medical intervention which leads to sterility does not always signal a changed, permissive attitude towards post-transition procreation. This is well illustrated in, inter alia, Norway, where legal gender recognition is obtained upon self-declaration as established in the Gender Recognition Act 2016, but legal parenthood continues to be determined pursuant to the (traditional) filiation rules enclosed in the Children Act 1981. ${ }^{97}$ Hence, a legal man who gives birth will be assigned the status of 'mother'. Similarly, Dunne explains that, despite ruling out sterilisation requirements for legal gender recognition, courts in Europe have often done so without challenging the justifications put forward by Legislators in support of sterilisation. ${ }^{98}$ In rejecting sterilisation as a disproportionate breach of physical integrity

95 A. Sørlie, 'Governing (Trans) Parenthood - The Tenacious Hold of Biological Connection and Heterosexuality' in D. Otto (ed.), Queering International Law: Possibilities, Alliances, Complicities, Risks (Abingdon, New York: Routledge, 2018) p. 187; Baars (n 64) 41.

96 Sørlie (n 95) 184.

97 Ibid 180. Denmark is another example. See P. Dunne, 'Recognising Transgender Parenthood on Birth Certificates: R (JK) v Secretary of State for the Home Department' (2015) (3) International Family Law 230-35. 
but failing to engage with its underlying rationales, Dunne argues, courts have left the assumption that sterilisation requirements pursue legitimate aims untouched or even restated it. $^{99}$

One particularly relevant example is offered by the 2011 decision of the German Constitutional Court which struck down the sterilisation clause originally included in the TSG $1980 .{ }^{100}$ In favour of maintaining this requirement, the Government claimed the alleged incompatibility of trans procreation with a family law system based on women who bear children and men who produce sperm - just like it did later in the case of $\mathrm{OH}$. In spite of declaring the sterilisation clause unconstitutional, the Constitutional Court argued that it can be ensured by law that the children concerned will, in spite of a parent's legal gender reassignment, always be legally assigned a father and a mother.' ${ }^{101}$ This seems to suggest that, although the Constitutional Court proved willing to detach legal gender recognition from biology somewhat, this was only because the fears over legal uncertainty (raised by the Government) could be addressed through alternative - ie legal - means. In other words, in the Constitutional Court's mind, the legal consequences of removing sterilisation could be regulated and, more importantly, a biological, heteronormative conception of parenthood could be assured by legal, instead of physical, interventions. ${ }^{102}$ Ultimately, this is exactly what happened in the case of $\mathrm{OH}$.

\section{ECtHR AND TRANS PARENTHOOD: LOOKING BACK IN TIME}

Attention is now directed to the ECtHR. This choice is guided by two rationales. First and foremost, the time has come for the Court to look for 'a place for the pregnant man ${ }^{103}$ within its jurisprudence on family relationships. The case of O.H. and G.H. has indeed reached Strasbourg, and the Court is expected to deliver its judgment over the next months. Secondly, the Court has become an increasingly important actor in the production, reproduction, and legitimisation of ideas about family life and parenting. As will be explained later in this section, it has - possibly unconsciously - conveyed messages about fathers' desirable qualities and attitudes towards their children through its judgments. ${ }^{104}$ In this respect, O.H. and G.H. clearly constitutes an important chance, and simultaneously a true test of the Court's engagement in (re-)framing what it means to be a 'father' today.

The Court has thus far only entered the terrain of trans parenthood on a couple of occasions. ${ }^{105}$ Interestingly, however, in the case of $X, Y$ and $Z v U K$, it was exactly the legal determination of the relationship between a trans father and his child born after transition which was at stake. ${ }^{106}$ In particular, the Court was asked to determine

99 Ibid.

1001 BvR 3295/07 (n 32).

101 Ibid.

102 Dunne (n 5) 568.

103 D. Gonzalez-Salzberg, Sexuality and Transsexuality under the European Convention on Human Rights: A Queer Reading of Human Rights Law (Oxford: Hart, 2019) p. 193.

104 Margaria (n 86).

105 In two cases, the Court was called to decide on the right to contact of a trans mother with her child, born prior to transition in the context of a (broken) heterosexual marriage: L.F. $v$ Ireland (dec.), Application No. 28154/95, 2 July 1997; P.V. v Spain, Application No. 35159/09, 30 November 2010. 
whether the refusal to register $\mathrm{X}$, a 'female-to-male transsexual', ${ }^{107}$ as the legal father of Z, a child born to X's female partner (Y) through donor insemination, was in breach of the right to respect for private and family life of the three applicants. The majority found that Article 8 could not, in this context, be interpreted as implying an obligation for the respondent state to formally recognise a person who is not the biological father as the father of a child. ${ }^{108}$ Persuaded by the lack of a common European approach and the sensitive nature of the ethical and moral issues raised by 'transsexuality', the Court granted a wide margin of appreciation to the UK. ${ }^{109}$ Subsequently, it undertook a lenient assessment of proportionality and concluded that national authorities had struck a fair balance between the competing interests involved: the Article 8's rights of the applicants and the alleged interest of the community 'in maintaining a coherent system of family law which places the best interests of the child at the forefront'. ${ }^{110}$

As has been argued elsewhere, ${ }^{111}$ this judgment exhibits a clear attachment to 'conventional fatherhood'. In discussing the applicability of Article 8, the Court did not hesitate to acknowledge that the applicants' situation resembled the life of a traditional heterosexual family in all its basic attributes and was indistinguishable from the traditional notion of family life for practical considerations. In particular, it was regarded as relevant that $\mathrm{X}$ and $\mathrm{Y}$ were to all appearances a male-female couple, who had cohabitated for a long time and had undertaken a parental project together, and that $\mathrm{X}$ had acted as Z's father since birth. ${ }^{112}$ While care was attached weight over biology with a view to establishing family life between $\mathrm{X}$ and $\mathrm{Z}$, the concreteness of the emotional bond existing between them did not prove sufficient to reach the threshold of legal fatherhood. In other words, X's non-adherence to the image of the 'conventional father' eventually made a difference for the final outcome. The lack of a biological connection in conjunction with X's trans identity proved decisive to rule out the previously established positive obligation to provide legal recognition to existing family ties, ${ }^{113}$ thereby contributing - together with the alleged lack of European consensus - to a lenient assessment of proportionality.

$X, Y$ and $Z v U K$ represents the Court's earliest decision on trans- and more generally LGBT parenthood. Despite concerning the (more specific) issue of parenthood, it arose against the broader backdrop of legal gender recognition in the UK at a time (1997) when the Court was not yet willing to recognise states' positive obligations in this field. As such, it could be, and has been, understood as the outcome of judicial (and societal) attitudes which would now be considered outmoded. ${ }^{114}$ According to Gonzalez-Salzberg, ${ }^{115} X, Y$ and $Z$ is to be viewed as implicitly 
overturned by the Court's case law since Goodwin $v$ UK and I $v U K,{ }^{116}$ which recognised the right of trans individuals to be granted full recognition of their gender transition. Gonzalez-Salzberg ${ }^{117}$ goes on to claim that this is further confirmed by the more recent ruling in A.P., Garçon and Nicot v France, ${ }^{118}$ where the Court clarified that making gender recognition conditional upon undergoing sterilising surgery or medical treatments likely to cause sterility breaches Article 8 . In ruling out sterility as an acceptable requirement for legal recognition of gender identity, the Court leaves open the possibility for trans individuals to become - or at least, to desire to become - biological parents and, albeit indirectly, acknowledges their 'familial character.' 119

However, on a broader look at the ECtHR case law on LGBTI families, family rights are still conceived as 'gendered and (hetero)sexualised'. ${ }^{120}$ The possibly most acute manifestation of this trend is to be found in the Court's attempt to preserve marriage as a 'special' and heterosexually exclusive institution. Apart from validating national bans on same-sex marriage, ${ }^{121}$ the Court has clarified that trans individuals have the right to marry only a person of the opposite sex to that attained through gender transition. ${ }^{122}$ Conversely, there exists no right to remain married to someone of the same sex, at least when the legal system offers the possibility to convert one's marriage into a civil partnership with 'almost identical' legal protection. ${ }^{123}$ The 'dominant ideology of the family' and, more specifically, the heterosexual couple at its centre, therefore, continue to pervade the Court's understanding of family ties, and its repercussions also reverberate through the concept of parenthood. ${ }^{124}$ Particularly emblematic in this sense is the case law on second-parent adoption by homosexual couples where the Court confirmed that being excluded from legal institutions reserved for married couples does not amount to discrimination. ${ }^{125}$ In so doing, the heteronormativity of legal regimes that seek to deny parental rights to LGBT individuals is left unchallenged and, as a result, the heterosexual married couple and their children continue to be granted privileges in compliance with Article $14 .^{126}$ The reading of the Convention offered by the ECtHR has therefore come to provide

116 Christine Goodwin v United Kingdom (GC), Application No. 28957/95, 11 July 2002; I v United Kingdom, Application No. 25680/94, 11 July 2002.

117 Gonzalez-Salzberg (n 103) 155.

118 A.P., Garçon and Nicot v France (n 30) para 135.

119 Gonzalez-Salzberg (n 103) 155. In the pending case, however, it is not the broader familial character, but the more specific paternal character of $\mathrm{OH}$ and his relationship with $\mathrm{GH}$, which is disputed. Ibid 94.

121 Schalk and Kopf v Austria, Application No. 30141/04; Oliari and Others v Italy, Application Nos. 18766/ 11 and 36030/11, 21 July 2015; Chapin and Charpentier v France, Application No. 40183/07, 9 June 2016; Orlandi and Others v Italy, Application Nos. 26431/12, 26742/12, 44057/12, and 60088/12, 14 December 2017. Goodwin v UK (n 116); I v UK (n 116). Hämäläinen v Finland (GC), Application No. 37359/09, 16 July 2014, para 87.

Margaria (n 86) 151; Gonzalez-Salzberg (n 103) 120; M. Sabatello, 'Advancing Transgender Family Rights Through Science: A Proposal for an Alternative Framework' (2011) 33 Human Rights Quarterly 59.

125 Gas and Dubois v France, Application No. 25951/07, 15 March 2012; X and Others v Austria, Application No. 19010/07, 19 February 2013. 
LGBT families with access to equal rights, only to the (limited) extent that they mimic the 'ideal', the 'conventional'. ${ }^{127}$

A similar way of proceeding can be observed in the Court's case law on fatherhood, under Article 8 alone and in conjunction with Article 14. As has been shown elsewhere, the definition of fatherhood endorsed by the Court incorporates both change and continuity with respect to the 'conventional paradigm'. ${ }^{128}$ 'The father' has been (re-)imagined as a human being displaying not only 'conventional' characteristics, but also participation in care or at least caring intentions. In other words, the Court has started to examine the claims of fathers through the additional lens of care. However, this trend should be interpreted cautiously not only because it shows some inconsistencies, ${ }^{129}$ but especially because of the special relationship it posits between 'conventional fatherhood' (Section 3) and care. In fact, the latter seems to be assigned (only) conditional importance: it tends to be taken into consideration only if expressed in a 'conventional' context or otherwise aimed at creating 'conventional fatherhood'. ${ }^{130}$ That is, extending rights to 'unconventional' fathers has often required reproducing the 'conventional' to some extent. In this sense, therefore, the judgment in $X, Y$ and $Z v U K$ does not stand out as exceptional in the Court's overall approach to fatherhood.

\section{WHAT TO EXPECT?}

Ruling in favour of the applicants in the case of O.H. and G.H. $v$ Germany, also depending on the reasoning, would have a transformative potential in many ways. First, it would signal a departure from a heteronormative understanding of fatherhood by accepting that one does not need to be born male in order to be a 'father'. Secondly, whilst not contesting the need for a biological connection per se, it would also break the biological link between sperm and father which, moreover, is typical of a cisgender understanding of fatherhood/reality. Thirdly, a finding of violation would mean contemplating fatherhood as a direct tie, thus overcoming the need for a mother to act as a father-child connector. This would advance the struggle for LGBT rights before the Court in more general terms by challenging the couple as the ideal model of intimacy to be achieved and to raise children. ${ }^{131}$ Fourthly, these multiple points of departure from 'conventional fatherhood' would quietly, yet essentially, contribute to valuing caring intentions and actual care as relevant or even sufficient parameters of legal fatherhood.

Whether this transformative potential will be realised depends on a plurality of factors. The existence of family life between $\mathrm{OH}$ and $\mathrm{GH}$ and, more generally, the applicability of Article 8 to the facts of the case are self-explanatory and undisputed. The real game will therefore be played in the second stage of review, where the Court will assess the proportionality of the contested decision to register $\mathrm{OH}$ as GH's 'mother'. The outcome of this assessment (and, by extension, of the case) is in turn likely to be contingent upon a variety of substantive and doctrinal variables. The 
reasoning of domestic courts (Section 2) suggests, for instance, that how the Court will conceptualise the child's right to know and, overall, whether the child's best interests will be constructed as in contradiction of or in line with a father's right to be recognised in accordance with his legal gender, might play a crucial role in Strasbourg's proceedings as well. Moreover, just like in any judgment of the Court, the intensity of the proportionality assessment will be additionally shaped by doctrinal considerations: for instance, whether the case is approached from the perspective of positive obligations or as a potential breach of a negative obligation ${ }^{132}$; and, certainly, the width of the margin of appreciation accorded to national authorities. The Court's practice indeed shows that there is a roughly inverse relationship between the doctrine of the margin of appreciation and proportionality: the wider the margin, the more lenient the review, and vice versa.

In O.H. and G.H., multiple (opposing) factors are relevant to define the width of the margin enjoyed by the state. The Court might consider this case to raise sensitive moral and ethical issues ${ }^{133}$ and - as domestic rulings examined in Section 2 suggest - to involve balancing between competing private (including the child's right to know one's origins) and public interests (ie coherence of the registration scheme). In line with well-established court practice, both factors lead to granting broad parameters of discretion to the state. ${ }^{134}$ At the same time, however, gender identity $^{135}$ and the legal parent-child relationship ${ }^{136}$ feature amongst the fundamental aspects of an individual's existence or identity which require strict scrutiny in accordance with the previous case law.

Another influencing factor which might be especially decisive for striking a balance between the others is that of European consensus. ${ }^{137}$ As a basic rule, whenever it is established that there is no European consensus either as to the relative importance of the interest at stake or as to the best means of protecting it, the Court will grant a wide margin of appreciation to national authorities and, at least in principle, will undertake a lenient scrutiny. Conversely, the existence of consensus generally contributes to restricting the margin and, therefore, to intensifying the strictness of review. In practice, however, the use of European consensus is not always

132 If the Court chooses to approach the case as involving positive obligations, this could point in the direction of granting a wider margin of appreciation to the state. On the potential implications of such a choice, see Concurring Opinion of Judge Ziemele (para 1) as well as Joint Dissenting Opinion of Judges Sajó, Keller, and Lemmens (para 4) in Hämäläinen v Finland (n 123); M. D’Amico and C. Nardocci, 'LGBT Rights and the Way Forward: The Evolution of the Case Law of the ECtHR in Relation to Transgender Individuals' Identity' (2016) 12 (2) ERA Forum 196.

133 This was also argued in $R$ (McConnell and $Y Y$ ) (n 14) s 62.

134 For example, Fretté v France, Application No. 65192/11, 26 June 2014, para 42; Evans v UK (GC), 6339/05, 10 April 2007, para 77; Dickson v UK (GC), Application No. 44362/04, 4 December 2007, para 78 .

135 For example, Van Kück v Germany, Application No. 35968/97, 12 June 2003, para 56; Y.Y. v Turkey (n 30) para 66; A.P., Garçon and Nicot v France (n 30) para 123; Y. T. v Bulgaria, Application No. 41701/ 16, 9 July 2020, para 63; Rana v Hungary, Application No. 40888/17, 16 July 2020, para 39. 
straightforward. ${ }^{138}$ The Court has adopted mutable criteria to establish what makes consensus, ${ }^{139}$ and the resulting variability is a well-known trait of, inter alia, the case law on trans rights. ${ }^{140}$ It is no coincidence that the latter is often understood as unequivocally displaying the agency of Strasbourg judges and, ${ }^{141}$ in a broader sense, LGBT rights are a prominent area in legal and social debates about Court-led social change. ${ }^{142}$

If the Court were to decide to give weight to the concrete regulations adopted by the States of the Council of Europe on the issue at stake in the pending case, the conclusion that a European consensus exists would be rather unrealistic. In almost all countries within the Council of Europe, a trans man who gives birth to a child is registered as the child's mother. ${ }^{143}$ Moreover, existing comparative studies show that, where children born after transition are concerned, legal approaches to the establishment of parenthood are largely not aligned, ${ }^{144}$ and there is an overall reluctance to determine legal parenthood in accordance with legal gender identity. ${ }^{145}$

In spite of this particularly significant body of evidence, ways could be imagined to use consensus which are conducive to support the position advocated by the applicant. As has occurred in previous cases, ${ }^{146}$ the Court might choose not to wait for the majority of the States of the Council of Europe to develop a shared approach to the issue at hand. It may extend its analysis to existing extra-European domestic sources as well as supranational and international legal documents. ${ }^{147}$ A trend, eg towards avoiding

138 A recent and comprehensive account is provided by C. Djeffal, 'Consensus, Stasis, Evolution: Reconstructing Argumentative Patterns in Evolutive ECHR Jurisprudence' in P. Kapotas and V.P. Tzevelekos (eds), Building Consensus on European Consensus: Judicial Interpretation of Human Rights in Europe and Beyond (Cambridge: Cambridge University Press, 2019) pp. 71-95.

139 On different levels and types of consensus, see K. Dzehtsiarou, European Consensus and The Legitimacy of the European Court of Human Rights (Cambridge: Cambridge University Press, 2015) pp. 14-16 and ch 3.

140 S. Choudhry and J. Herring, European Human Rights and Family Law (Oxford; Portland: Hart, 2010) pp. 15 and 16; Gonzalez-Salzberg (n 103) 194.

141 L.R. Helfer and E. Voeten, 'International Courts as Agents of Legal Change: Evidence from LGBT Rights in Europe' (2014) 68 International Organisation 77-110.

142 Johnson (n 19); Gonzalez-Salzberg (n 103).

143 This fact was also raised by domestic courts: Re TT and $Y Y$ (n 40) para 229; R (McConnell and YY) (n 14) para 79; BGH (n 15) para 45. An exception is Sweden, where a legal reform (of the Föräldrabalk, roughly 'Parenthood Act') providing for alignment between legal gender and parenthood entered into force on 1 January 2019. Even before this legislative change, in 2015, the Stockholm Court of Appeal (Case No. 3201-14, 9 July 2015) decided that a trans man who had given birth after transition had to be registered as 'father' rather than 'mother', and that doing otherwise would breach the trans father's right to respect for private life under Art 8 ECHR.

144 Scherpe and Dunne (n 28) 659.

145 M. van den Brinck and P. Dunne, Trans and Intersex Equality Rights in Europe - A Comparative Analysis (Brussels: European Commission, 2018) p. 61. See also TGEU (n 20).

146 In the area of LGBT rights, examples include Goodwin $v$ UK (n 116) para 85; Y.Y. v Turkey (n 30) para 108; A.P., Garçon and Nicot v France (n 30) para 124; Hämäläinen v Finland (n 123) Joint Dissenting Opinion of Judges Sajó, Keller, and Lemmens, para 5; Vallianatos and Others v Greece, Application Nos. 29381/09 and 32684/09, 7 November 2013, para 91.

147 In some Canadian and US states, it is indeed possible for a trans man who gives birth to be registered as the child's father or parent. For instance, in Ontario, see the story of Jay Wallace who was registered as the father of the child he had given birth to: K. Nelson, 'The Small Person Acquisition Project' 2011, https://www.thirdcoastfestival.org/feature/small-person-acquisition-project (last access on 2 June 2020); and the All Families Are Equal Act, which entered into force on 1 January 2017: https://www.on 
incongruence between lived and legal realities of trans individuals, could result in being sufficient to grant a narrow margin. The Court could also decide to approach consensus identification 'at the level of principles', ${ }^{148}$ insisting for instance on an alleged agreement that trans individuals should be afforded full legal recognition in all areas of life. ${ }^{149}$ In the pending case, therefore, European consensus could certainly be an obstacle to jurisprudential evolution, but also work as a tool for supporting the adoption of innovative solutions which would reinvent fatherhood beyond the conventional paradigm.

By identifying a multiplicity of potentially relevant factors, this account emphasises that Strasbourg judges enjoy some discretion in modelling their doctrinal path. Putting aside the criticism it often attracts, ${ }^{150}$ this discretion should be read as suggesting that doctrines of interpretation and moral views cannot be easily distinguished and often operate jointly in shaping the Court's jurisprudence. ${ }^{151}$ In other words, the flexibility inherent to the application of European consensus, as well as other doctrines, might be the entry point for the moral positions held by the judges sitting in each individual case, and take human rights standards either further than expected or not. Consequently, the construction of fatherhood endorsed by the Court in O.H. and G.H. will most likely not be the mere 'product of the application of doctrines. Rather, the Court's moral standpoint on trans fatherhood might be one (additional) factor, or even the main factor, which influences the exact doctrinal path taken by the Court and the final outcome. If the Court's moral policy on fatherhood and, broader, LGBT families continue to restate 'the conventional' as a point of reference, the chances that the transformative potential of O.H. and G.H. will be realised are quite limited. It is indeed difficult to imagine how the applicants could manage to persuade the Court of OH's similarity to 'conventional fatherhood'. For the time being, however, amongst the few things which can be predicted realistically, is that whether the Court's judgment will break away from 'conventional fatherhood' and make care a paternal trait will - to some extent - also be a 'matter of choice'.

\section{CONCLUDING THOUGHTS: DE-GENDERING LEGAL PARENTHOOD AS THE WAY TO GO?}

The cases of McConnell and $\mathrm{OH}$, and trans masculine experiences of pregnancy and birth overall, are precious opportunities for the social and legal rethinking of what it means to be a father today. Allowing trans men who give birth to be recognised as 'fathers' of their children, however, requires the contestation of deeply entrenched

tario.ca/laws/statute/s16023 (last access on 2 June 2020). Another relevant source could be PACE, Resolution 2239 (2018) Private and Family Life: Achieving Equality Regardless of Sexual Orientation, s 4.6, 10 October 2018.

148 Dzehtsiarou (n 139) 16.

149 A similar point is made by Hannah Markham QC, legal representative of McConnell, before the High Court. See Re TT and YY (n 40) para 67.

150 For example, Choudhry and Herring (n 140) 16; P.G. Carozza, 'Uses and Misuses of Comparative Law in International Human Rights: Some Reflections on the Jurisprudence of the European Court of Human Rights' (1997-1998) 73 Notre Dame Law Review 1217-37; M. Ambrus, 'Comparative Law Methods in the Jurisprudence of the European Court of Human Rights in the Light of the Rule of Law' (2009) 2 (3) Erasmus Law Review 353-71.

151 Johnson (n 19) ch 3; H. Gülalp, 'Secularism and the European Court of Human Rights' (2010) 16 (3) European Public Law 455-71. 
gendered assumptions about reproduction and parenting, and thus overcoming significant challenges. First, it entails departing from 'conventional fatherhood' and, in particular, renouncing the long-presumed indispensability of biology and heteronormativity as defining features of the father figure. Further, it involves acknowledging care, an attribute which has been traditionally considered as feminine and maternal, as a relevant parameter for attributing legal fatherhood. All in all, it requires the recognition that men, and even more controversially trans men, are able to care, and that trans men are not 'mothers' if they do (care).

De-gendering legal parenthood has therefore been often advanced as an easier to digest or even desirable solution to determine the parental status of trans men giving birth to their children and, by extension, of trans parents. ${ }^{152}$ The idea is to abandon the gender-specific and dichotomous terminology used in registration laws, which does not leave room for parents other than mothers and fathers, thus replacing the legal categories of 'motherhood' and 'fatherhood' with the gender-neutral term 'parenthood'. This solution would bring multiple advantages, many of which go beyond the context of trans parenthood and might have a structural impact. It would certainly contribute to reducing the power of heteronormativity. It would further enable the law to accommodate a wide(r) variety of 'unconventional' families and it might even be an inevitable turn in the face of an increasing access to adoption and ART by same-sex couples. ${ }^{153}$

In the context of trans parenthood, providing for a standardised status as 'parent' would solve the issue of whether parental status should reflect the birth-assigned gender or the legally acquired gender once for all. It would work as an effective semantic compromise between different individual preferences - ie those who seek and those who do not seek alignment of gender and parenthood. ${ }^{154}$ While McConnell and $\mathrm{OH}$ perceive themselves as fathers and would like to be legally recognised as such, there are indeed other trans men who conversely self-identify as mothers of the children they gave birth to. ${ }^{155}$ Moreover, de-gendering registration laws would also cater to those parents who transition to a non-binary gender form rather than to the male or female gender. ${ }^{156}$

Without devaluing these practical and structural benefits of de-gendering legal parenthood, it is important to reflect on whether the time is ripe for such a shift. Back in the 1990s, Fineman warned us of some of the undesired consequences of

152 Scherpe and Dunne (n 28) 659; M. van den Brink and J. Tigchelaar, 'The Equality of the (Non)transparent: Women Who Father Children' in M. van den Brink, S. Burri, and J. Goldschmidt (eds), Equality and Human Rights: Nothing But Trouble? Liber Amicorum Titia Loenen (Utrecht: Netherlands Institute of Human Rights, 2015) p. 259; S. McGuinness and A. Alghrani, 'Gender and Parenthood: The Case for Realignment' (2008) 16 Medical Law Review 282.

153 J.M. Scherpe, 'Breaking the Existing Paradigms of Parent-Child Relationships' in G. Douglas, M. Murch, and V. Stephens (eds), International and National Perspectives on Child and Family Law - Essays in Honour of Nigel Lowe (Cambridge: Intersentia, 2018) p. 347.

154 Scherpe and Dunne (n 28) 659; Karaian (n 91) 224.

155 Karaian (n 91) 226.

156 R. Pearce, 'If a Man Gives Birth, He's the Father - The Experiences of Trans Parents' The Conversation, 25 September 2019, https://theconversation.com/if-a-man-gives-birth-hes-the-father-the-experiences-oftrans-parents-124207?fbclid=IwAR1Anz8U_bgwiCPW1VNxpgABkawyfqmS98msx6tDzAQuRquxfze5 YVjMK9k (last access on 2 June 2020). 
de-gendering family laws for mothers. ${ }^{157}$ Replacing mothering with parenting has failed to deliver on its promises of (substantive) equality because it has meant that the unique role of mothers in childcare was largely ignored and no concomitant reconstruction of the institution of fatherhood has taken place. ${ }^{158}$ Even though Fineman's reflections referred to the US context and almost 30 years have passed, some doubts remain as to whether de-gendering legal parenthood is the way to go in the wider field of family law. The social and legal constructions of 'fatherhood' and 'motherhood' indeed continue to be sustained and reinforced by many stereotypical assumptions which keep men and fathers out of the childcare picture, with significant repercussions on the lives of women and children. While an increasing number of men are eager to spend more time at home and participate in childcare, societal and legal barriers remain. ${ }^{159}$ Therefore, an argument could be made that fatherhood - as a legal institution - (still) needs specific measures which confront and redress fathers' expected role as breadwinners and/or secondary carers.

Additionally, jumping directly to de-gendering legal parenthood might entail skipping a step which holds radical transformative potential for 'disestablishing the gender order. ${ }^{160}$ If the ultimate and overarching aim is the legal recognition of diverse, caring family relationships, de-gendering legal parenthood may be a shortcut which would result in dragging out the process. Rather, de-gendering caring roles by insisting on a reconstruction of fatherhood around care might be a first, necessary step on the longer road to achieving legal support and substantive equality for all parents and children.

\section{ACKNOWLEDGEMENT}

I would like to thank Daniela Alaattinoğlu, Peter Dunne, Stefano Osella, and Theresa Anna Richard for their insightful comments on an earlier draft. Their input made my final reflections much richer and more nuanced. Usual disclaimers apply.

157 M.A. Fineman, The Neutered Mother, The Sexual Family and Other Twentieth Century Tragedies (New York: Routledge, 1995).

158 Ibid 67, 68; M.A. Fineman, 'Fatherhood, Feminism and Family Law' (2001) 32 (4) McGeorge Law Review 1043.

159 E. Ruspini, 'Changing Femininities, Changing Masculinities - Social Change, Gender Identities and Sexual Orientations' (2007) 12 (1) Sociological Research Online 3.9.

160 This expression is taken from R. Rubio-Marín, 'The (Dis)establishment of Gender: Care and Gender Roles in the Family as a Constitutional Matter' (2016) 13 (4) International Journal of Constitutional Law 787-818. 